\title{
INHIBITION OF FORMATION OF CONJUGATED DIENES IN LINSEED OIL
}

\author{
Māra Kūka\#", Ilze Čakste, and Pēteris Kūka \\ Latvia University of Life Sciences and Technologies, 2 Lielā Str., Jelgava LV-3001, LATVIA \\ \# Corresponding author, mara.kuka@llu.Iv
}

Communicated by Inga Ciproviča

\begin{abstract}
Oxidation of fats and oils reduces the nutritional value of food and causes various health problems. The addition of antioxidants prevents the oxidation of fats in the food. The antioxidant activity of antioxidants represents the ability to inhibit the process of oxidation. The antioxidant activity of herbal extracts has usually been assessed in a linoleic acid emulsion system. The aim of the present study was to evaluate inhibition of conjugated diene formation in Latvian linseed oil. Ethanol extract of the calyx of Hibiscus sabdariffa L., vanillin, $\alpha$-tocopherol and 2,6-di-tert-butyl-4methylphenol as additives were compared for their antioxidative activity. The samples of linseed oil with additives were incubated for $24 \mathrm{~h}$ at $60^{\circ} \mathrm{C}$ and then analysed using UV spectrophotometry $(\lambda=234 \mathrm{~nm})$. The antioxidant activity of additives was characterised by the percentage of formation of conjugated dienes. The ability of additives to inhibit oxidation in linseed oil decreases as follows: vanillin, 2,6-di-tert-butyl-4-methylphenol and $\alpha$-tocopherol. Our results indicate that linseed oil can be used to test antioxidative activity of substances.
\end{abstract}

Key words: antioxidant activity, Hibiscus sabdariffa L., vanillin, $\alpha$-tocopherol, 2,6-di-tert-butyl-4methylphenol.

\section{INTRODUCTION}

Since the $15^{\text {th }}$ century, linseed oil has been used to make varnishes and oil-based house paints for treating wooden surfaces, and in manufacture of linoleum etc. (Juita et al., 2012). In the past decades linseed oil is increasingly being used as a source of polyunsaturated fatty acids in food (Sharav et al., 2014). Linseed oil contains high amounts of unsaturated fatty acids, mostly $\alpha$-linolenic acid (ALA C18:3n-3), which forms 52-60\% (Angers et al., 1996; Nykter et al., 2006; Juita et al, 2012; Rubilar et al., 2012) of the total fatty acid content. In most other oil types $\alpha$-linolenic acid is present in small amounts - below $1 \%$ (Juita et al., 2012). $\alpha$-linolenic acid is an essential component of healthy food and polyunsaturated acids are known to prevent the development of cardiovascular and inflammatory diseases, depression and possess cardioprotective effect (Garg et al., 2006; Rubilar et al., 2012).

The chemical structure and properties of unsaturated fatty acids and high content of these acids in linseed oil (around 90\%) are the main factors why linseed oil can be readily oxidised (Hamed and Abo-Elwafa, 2012; Sharav et al., 2014). Lipid oxidation is one of the primary mechanisms of deterioration of quality in flavour, colour, texture, nutritive value and may produce toxic compounds in foods. The main problem in the quality of oils, particularly for those that are highly unsaturated, is lipid oxidation during storage and food processing.

One of the first steps in the oxidation of polyunsaturated fatty acid is hydrogen abstraction from the active methylene group and the product is usually stabilised by a molecular rearrangement to form a conjugated diene (Antolovich et al., 2002). Conjugated dienes exhibit an absorption maximum at $234 \mathrm{~nm}$ and absorption values are further used to characterise concentration of dienes in oils (White, 1995; Frankel, 2005). The conjugated dienes and also peroxide value are often used to measure primary oxidation products and characterise quality of oils used in the food industry (Abuzaytoun and Shahidi, 2006).

The addition of natural and synthetic antioxidants prevents the oxidation of fats in food; thus, antioxidant activity represents the ability to inhibit the process of oxidation (Tirzitis and Bartosz, 2010). Some components in natural products such as flavonoids, anthocyanins and phenolic compounds are known to function as radical scavengers (Duh and Yen, 1997; Rudnik et al., 2001; Mau et al., 2004; Stoilova et al., 2007; Gutierrez et al., 2013; Shalaby and Shanab, 2013; Tan and Lim, 2015). Antioxidant activity of herbal extracts is usually characterised by their ability to decrease the formation of conjugated dienes using linoleic acid or methyl linoleate as substrates. The aim of the pres- 
ent study was to evaluate inhibition of conjugated diene formation in Latvian linseed oil.

\section{MATERIALS AND METHODS}

Cold pressed unrefined linseed oil from seeds manufactured by "Iecavnieks" Ltd, was used for studies. As antioxidants were used vanillin, 2,6-di-tert-butyl-4-methylphenol (DTBMP), $\alpha$-tocopherol and ethanol extract of calyxes of Hibiscus sabdariffa L.

Analyses of chemical parameters of linseed oil. Acid value (AV) was determined by titration with $\mathrm{KOH}$ solution (indicator phenolphthalein) and calculated as $\mathrm{mg}$ of $\mathrm{KOH}$ per gram of oil. Peroxide value (PV) was determined by spectrophotometric ferric thiocyanate method. Briefly, the method is based on the ability of hydroperoxides to oxidise ferrous ions $\left(\mathrm{Fe}^{2+}\right)$ to ferric ions $\left(\mathrm{Fe}^{3+}\right)$ in an acidic medium. The used standard curve was produced using an 0.1 $\mathrm{mg} \cdot \mathrm{ml}^{-1} \mathrm{Fe}^{3+}$ standard work solution. The absorbance of the ferric thiocyanate complex was measured at $\lambda=505 \mathrm{~nm}$ using an UV/Vis spectrophotometer Jenway UV 6405. PV was expressed as miliequivalents of oxygen per kilogram of oil (Eymard and Genot, 2003). Iodine value (IV) was determined by the Kaufmann method. In brief, a sample of oil was mixed with an excess of bromine. The unused bromine was reduced to bromide with iodide and the amount of iodine formed in this reaction was determined by titration with sodium thiosulfate solution. IV was expressed as grams of iodine per $100 \mathrm{~g}$ of oil (Matiseks et al., 1998). Saponification value (SV) was determined as follows: the sample of oil was saponified with $\mathrm{KOH}$ ethanol solution. The unused $\mathrm{KOH}$ was determined by titration with hydrochloric acid (indicator phenolphthalein). SV was expressed as mg of KOH per gram of oil (Matiseks et al., 1998).

Hydroperoxides from polyunsaturated acids form conjugated dienes $(\mathrm{CD})$ that were measured quantitatively by UV spectrophotometric measurement. $0.100-0.120$ g oil samples were dissolved in 2,2,4-trimethylpentane in $50 \mathrm{ml}$ volumetric flasks. The absorbance was read at $234 \mathrm{~nm}$ in a $1 \mathrm{~cm}$ quartz cell using UV/VIS spectrophotometer Jenway UV 6405. 1\% methylstearate solution in 2,2,4-trimethylpentane was used as a blank (White, 1995; Matiseks et al., 1998; Frankel, 2005). The concentration of conjugated dienes [CD] of the oil samples was calculated according to the following equation:

$[C D]=\frac{A}{\varepsilon \cdot l}$, where

A - absorbance,

$\varepsilon=2.525 \cdot 10^{4} \mathrm{M}^{-1} \cdot \mathrm{cm}^{-1}-$ molar absorptivity of linoleic acid hydroperoxide,

1 - optical path of the quartz cell - $1 \mathrm{~cm}$ (Peg, 2001; Abuzaytoun and Shahidi, 2006).

The conjugated diene value (CD value) was calculated as follows:
$C D_{\text {value }}=\frac{[C D] \cdot 5 \cdot 10^{4}}{m}$, where

$5 \cdot 10^{4}$ - factor that encompasses the volume of 2,2,4-trimethylpentane $(50 \mathrm{ml})$ used to dissolve the oil sample for determination of $\mathrm{CD}$ concentration in $\mu \mathrm{mol}$, $\mathrm{m}$ - sample weight, g (Peg, 2001).

Vanillin, 2,6-di-tert-butyl-4-methylphenol (DTBMP) and $\alpha$-tocopherol were added to linseed oil to reach an end concentration of $0.01 \%$ and dry extract of Hibiscus sabdariffa L. - end concentration of $1 \%$. The mixture was homogenised and incubated at $60{ }^{\circ} \mathrm{C}$ for $24 \mathrm{~h}$. The antioxidative effect (A.E.) of extract of Hibiscus sabdariffa L, 2,6-di-tertbutyl-4-methylphenol (DTBMP), vanillin and $\alpha$-tocopherol was calculated according to the following equation:

$A . E .=\frac{\Delta A(C)-\Delta A}{\Delta A(C)}$, where

$\Delta \mathrm{A}$ - increase of absorption at $234 \mathrm{~nm}$ during the incubation time,

$\triangle \mathrm{A}(\mathrm{C})$ - the corresponding increase in the control (Lingnert et al., 1979).

The percentage inhibition (I\%) of conjugated dienes (CD) formation in linseed oil was calculated by the following equation (Stoilova et al., 2007):

$I \%=100 \frac{C D_{\text {value }} \text { increase of sample }}{C D_{\text {value }} \text { increase of control }} \cdot 100$

Preparation of extract from Hibiscus sabdariffa L. calyxes

A sample of $10 \mathrm{~g}$ of Hibiscus sabdariffa L. calyxes was extracted by stirring with $100 \mathrm{ml}$ of ethanol at $25^{\circ} \mathrm{C}$ for $24 \mathrm{~h}$. The ethanol extract was filtered and then rotary evaporated at $30{ }^{\circ} \mathrm{C}$ to dry mass.

Data analysis. All presented data are the averages of triplicate measurements. The results are presented as the mean \pm standard deviation. Data analysis was performed using in-built analysis of Microsoft Excel 2010.

\section{RESULTS}

Chemical parameters of linseed oil. Chemical parameters of cold pressed unrefined linseed oil from Latvia are summarised in Table 1. Acid value of linseed oil was within the limit of up to $4 \mathrm{mg} \mathrm{KOH}$ per $\mathrm{g}$ of oil, according to the Codex Alimentarius Commission standard for cold pressed oils (Anonymous, 1999; Prescha et al., 2014). The peroxide value (PV) of linseed oil did not exceed the recommended upper limit for cold pressed oils of 15 milliequivalents of oxygen per kilogram of oil (Anonymous, 1999; Prescha et al., 2014). Iodine value (IV) indicated that studied linseed oil was highly polyunsaturated oil. Saponification value (SV) of oil is shown in Table 1 and indicates that 
CHEMICAL PARAMETERS OF LINSEED OIL

\begin{tabular}{lcll}
\hline \multicolumn{1}{c}{ Parameter } & Value & Unit of measurement \\
\hline Iodine value & $187 \pm 1$ & grams of $\mathrm{I}_{2}$ per $100 \mathrm{~g}$ oil \\
Saponification value & $194 \pm 1$ & $\mathrm{mg}$ of $\mathrm{KOH}$ per $1 \mathrm{~g}$ oil \\
Acid value & $1.20 \pm 0.01$ & $\mathrm{mg}$ of $\mathrm{KOH}$ per $1 \mathrm{~g}$ oil \\
Peroxide value & $3.0 \pm 0.02$ & meq of $\mathrm{O}_{2}$ per $1 \mathrm{~kg}$ oil
\end{tabular}

Data are presented as mean $\pm \mathrm{SD}(\mathrm{n}=3)$.

triacylglycerols in the linseed oil contain long chain fatty acid moieties.

Conjugated dienes assay. The absorbance at $\lambda=234 \mathrm{~nm}$ was measured for both the linseed oil samples before and after incubation at $60{ }^{\circ} \mathrm{C}$ for $24 \mathrm{~h}$ (control) and the oil samples with additives: vanillin, DTBMP, a-tocopherol and dried ethanol extract of Hibiscus sabdariffa L. (Fig. 1). Antioxidative effects of the additives used were calculated from the data obtained with UV-Visible spectrophotometry. The antioxidative effect of additives decreased as follows: vanillin, 2,6-di-tert-butyl-4-methylphenol and $\alpha$-tocopherol (Fig. 2). The sample of linseed oil that was emulsified with extract of Hibiscus sabdariffa L. had antioxidative effect value 0.93

The absorbance measured at $\lambda=234 \mathrm{~nm}$ was used to evaluate the formation of conjugated dienes. The concentration of conjugated dienes [CD] and value of conjugated dienes $\left(\mathrm{CD}_{\text {value }}\right)$ are shown in Table 2. Vanillin, 2,6-di-tert-butyl4-methylphenol and $\alpha$-tocopherol improved the stability of linseed as indicated by lower formation of conjugated

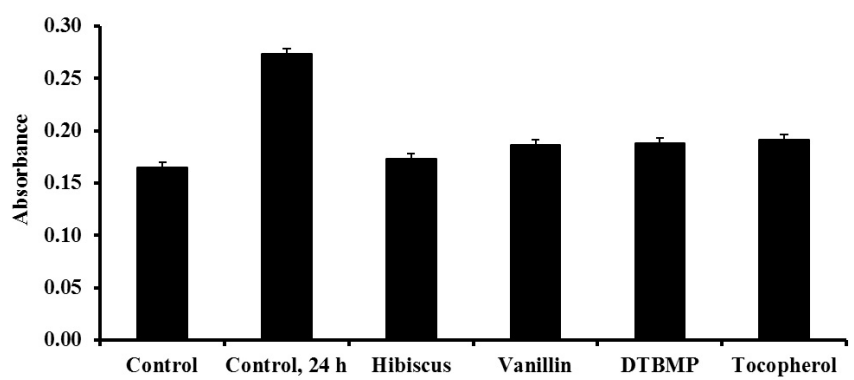

Fig. 1. Absorbance of linseed oil with additive after incubation for $24 \mathrm{~h}$ at $60{ }^{\circ} \mathrm{C}$. Data are presented as mean $\pm \mathrm{SD}(\mathrm{n}=3)$.

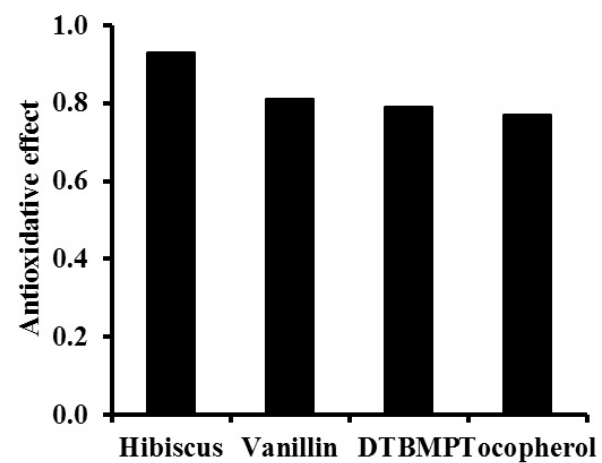

Fig. 2. Antioxidative effect of additives in linseed oil after incubation for $24 \mathrm{~h}$ at $60^{\circ} \mathrm{C}$
FORMATION OF CONJUGATED DIENES CD IN LINSEED OIL

\begin{tabular}{l|c|c}
\hline \multicolumn{1}{c|}{ Additive } & $\begin{array}{c}{[\mathrm{CD}],} \\
\mu \mathrm{M} \mathrm{mmol} \mathrm{cm}{ }^{-3}\end{array}$ & $\begin{array}{c}\text { CD value, } \\
\mu \mathrm{mol} \mathrm{g}^{-1}\end{array}$ \\
\hline Without additive & $6.53 \cdot 10^{-6}$ & $2.62 \pm 0.06$ \\
Without additive after $24 \mathrm{~h}$ at $60^{\circ} \mathrm{C}$ & $1.08 \cdot 10^{-5}$ & $4.32 \pm 0.06$ \\
Vanillin & $7.37 \cdot 10^{-6}$ & $2.94 \pm 0.05$ \\
DTBMP & $7.44 \cdot 10^{-6}$ & $2.98 \pm 0.07$ \\
$\alpha$-Tocopherol & $7.56 \cdot 10^{-6}$ & $3.02 \pm 0.09$ \\
Extract of Hibiscus sabdariffa $\mathrm{L}$. & $6.91 \cdot 10^{-6}$ & $2.76 \pm 0.05$
\end{tabular}

Data are presented as mean \pm SD $(n=3)$.

dienes (CD) compared with the control - oil without additives (Table 2). Value of conjugated dienes in linseed oil without additives (control) incubated for $24 \mathrm{~h}$ at $60{ }^{\circ} \mathrm{C}$ increased by $64.9 \%$, with vanillin - by $12.2 \%$, DTBMP by $13.7 \%$ and $\alpha$-tocoferol - by $15.3 \%$. The antioxidant activity of additives was characterised by the percentage of formation of conjugated dienes. The ability of additives to inhibit the process of oxidation in linseed oil decreases as follows: vanillin $81.2 \%$, 2,6-di-tert-butyl-4-methylphenol $78.8 \%$ and _-tocopherol $76.5 \%$. The sample of linseed oil emulsified with dried ethanol extract of Hibiscus sabdariffa L. had a concentration of conjugated dienes $6.91 \cdot 10^{-6} \mathrm{mmol}$ $\mathrm{cm}^{-3}$ and the corresponding conjugated dienes value was $2.76 \pm \mu \mathrm{mol} \cdot \mathrm{g}^{-1}$. Extract of calyxes of Hibiscus sabdariffa L. improved the stability of linseed oil as indicated by lower formation of conjugated dienes (CD) compared with the control - oil without additives (Table 2). Value of conjugated dienes in linseed oil with extract of Hibiscus sabdariffa L. incubated for $24 \mathrm{~h}$ at $60{ }^{\circ} \mathrm{C}$ increased by $4.8 \%$. The ability of extract of Hibiscus sabdariffa L. to inhibit the process of oxidation in linseed oil was $91.8 \%$.

\section{DISCUSSION}

Linseed oil with its high levels of polyunsaturated fatty acids, especially $\alpha$-linolenic acid, is very prone to oxidation. Therefore, it is important to continue studies on antioxidants and ways to enhance stability against oxidation (Rudnik et al., 2001; Abuzaytoun and Shahidi, 2006; Hamed and Abo-Elwafa, 2012; Juita et al., 2012; Rubilar et al., 2012; Oladimeji et al., 2013; Prescha et al., 2014; Sharav et al., 2014). The present study quantitatively characterised various parameters in cold pressed unrefined linseed oil from seeds cultivated in Latvia. Linseed oil is characterised as a highly polyunsaturated oil and therefore it would be necessary to provide additional protection against oxidation to improve overall stability and, thus, increase usability of this oil for food industry.

Tested linseed oil corresponds to quality standards; the acid value and the peroxide value of oil did not exceed the recommended limit for cold pressed oils according to the Codex Alimentarius Commission standard (Anonymous, 1999). $\alpha$-tocopherol and 2,6-di-tert-butyl- 4-methylphenol are well-known antioxidants (Mau et al., 2004). Vanillin 
(4-hydroxy-3-methoxybenzaldehyde) is a phenolic aldehyde that is widely used in foods, beverages, cosmetics, drugs and has been reported to exhibit multifunctional beneficial effects (Tai et al., 2011). Because vanillin contains phenolic hydroxyl group, it can protect unsaturated fatty acids from oxidation. The present study showed that vanillin is a potent antioxidant and its antioxidative effect and the ability to inhibit the process of formation of conjugated dienes in linseed oil was higher than that of 2,6-di-tert-butyl-4methylphenol and $\alpha$-tocopherol (Figure 2 and Table 2). In previous studies using multiple assay systems it was shown that vanillin possesses antioxidant activity and has much stronger antioxidant activity than ascorbic acid (Tai et al., 2011), but it was not known to prevent diene conjugation resulting from lipid oxidation.

Conjugated dienes are often used to determine primary oxidation products or to characterise antioxidative properties (Abuzaytoun and Shahidi, 2006). Antioxidant activity of herbal extracts is determined by their ability to inhibit formation of conjugated dienes. In the present study we used cold pressed unrefined linseed oil as a substrate to determine the ability to inhibit formation of conjugated dienes. The antioxidant-like activity of ethanol extract of the calyxes of Hibiscus sabdariffa L. was found to be $91.8 \%$. Previously it was shown that water extract of the calyx of $\mathrm{Hi}$ biscus sabdariffa L. has antioxidant activity $93.0 \%$, determined by the thiocyanate method using linoleic acid as a substrate (Duh and Yen, 1997). The antioxidative effect may be explained by the presence of flavonoids, quercetin and ascorbic acid in flowers of Hibiscus sabdariffa L. (Kumar and Singh, 2012).

In conclusion, the obtained data indicate that ethanol extract of calyxes of Hibiscus sabdariffa L. inhibits the formation of conjugated dienes in linseed oil. The ability of additives to inhibit oxidation in linseed oil decreases as follows: vanillin, 2,6-di-tert-butyl-4 methylphenol and $\alpha$-tocopherol. Moreover, our results indicate that linseed oil can be used as a substrate to test antioxidative activity.

\section{REFERENCES}

Abuzaytoun, R., Shahidi, F. (2006). Oxidative stability of flax and hemp oils. J. Amer. Oil Chem. Soc., 83 (10), 855-861.

Angers, P., Morales, M. R., Simon, J. E. (1996). Fatty acid variation in seed oil among ocimum species. J. Amer. Oil Chem. Soc., 73, 393-395.

Anonymous (1999). Food standards programme. In: Codex Alimentarius Commission. Codex standards for named vegetable oils. CX-STAN 210-1999.

Antolovich, M., Prenzler, P. D., Patsalides, E., McDonald, S., Robards, K. (2002). Methods for testing antioxidant activity. Analyst, 127 (1), 183-198.

Duh, P., Yen, G. (1997). Antioxidative activity of three herbal water extracts. Food Chem., 60 (4), 639-645.

Eymard, S., Genot, C. (2003). A modified xylenol orange method to evaluate formation of lipid hydroperoxides during storage and processing of smallpelagic fish. Eur. J. Lipid Sci. Technol., 105, 497-501.

Frankel, E. N. (2005). Lipid Oxidation. The Oily Press, Bridgwater, England. $470 \mathrm{pp}$.

Received 31 January 2017

Accepted in the final form 29 October 2017
Garg, M. L., Wood, L. G., Singh, H., Moughan, P. J. (2006). Means of delivering recommended levels of long chain n-3 polyunsaturated fatty acids in human diets. J. Food Sci., 71, 66-71.

Gutierrez, M. C., Rocca, P. D., De Seta, E. G., Reina, F. (2013). Evaluation of the antioxidant activity of ethanolic extracts of some varieties of onion. Food Nutr. Sci., 4, 1260-1265.

Hamed, S. F., Abo-Elwafa, G. A. (2012). Enhancement of oxidation stability of flax seed oil by blending with stable vegetable oils. J. Appl. Sci. Res., 8 (10), 5039-5048.

Juita, J., Dlugogorski, B. Z., Kennedy, E. M., Mackie, J. C. (2012). Low temperature oxidation of linseed oil: Review. Fire Sci. Rev., 1 (3), 1-36. Available from: https://firesciencereviews.springeropen.com/articles (accessed 16 January 2017).

Kumar, A., Singh, A. (2012). Review on Hibiscus rosa sinensis. Int. J. Res. Pharm. Biomed. Sci., 3 (2), 534-538.

Lingnert, H., Vallentin, K., Eriksson, C. E. (1979). Measurement of antioxidative effect in model system. J. Food Process. Preserv., 3, 87-103.

Mau, J., Huang, P., Huang, S., Chen, C. (2004). Antioxidant properties of methanolic extracts from two kinds of Antrodia camphorata mycelia. Food Chem., 86, 25-31.

Matiseks, M., Šnēpels, F. M., Šteiners, G. (1998). Pārtikas analītiskā ķīmija [Food Analytical Chemistry]. Latvijas universitāte, Rīga. 456 lpp. (in Latvian).

Nykter, M., Kymalainen, H. R., Gates, F., Sjoberg, A. M. (2006). Quality characteristics of edible linseed oil. J. Agric. Food Sci, 15, 402-413.

Oladimeji, T. A., Kennedy, O. E., Ehigiator, O. F., Nwakamma, E. G. (2013). Effects of antioxidants on the oxidative stability of vegetable oil at elevated temperature. Int. J. Appl. Sci. Technol., 3 (5), 107-115.

Peg, R. J. (2001). Determination of conjugated dienes and trienes. In: Wrolstad, R, E. (Ed.). Current Protocols in Food Analytical Chemistry. John Wiley \& Sons, New York, pp. D2.1.1-D2.1.3.

Prescha, A., Grajzer, M., Dedyk, M., Frajeta, H. (2014). The antioxidant activity and oxidative stability of cold-pressed oils. J. Amer. Oil Chem. Soc., 91 (8), 1291-1301.

Rubilar, M., Morales, E., Saez, R., Acevedo, F., Palma, B., Villaroel, M., Shene, C. (2012). Polyphenolic fractions improve the oxidative stability of microencapsulated linseed oil. Eur. J. Lipid Sci, Technol., 114, 760-771.

Rudnik, E., Szczucinska, A., Gwardiak, H., Szulc, A., Winiarska, A. (2001). Comparative studies of oxidative stability of linseed oil. Thermochimica Acta, 370, 135-140.

Shalaby, E. A., Shanab, S. M. M. (2013). Comparison of DPPH and ABTS assays for determining antioxidant potential of water and methahnol extracts of Spirulina platensis. Indian J. Geo-Marine Sci., 42 (5), 556-564.

Sharav, O., Shim, Y. Y., Okinyo-Owiti, D. P., Sammynaiken, R., Reaney, M. J. T. (2014). Effect of cyclolinopeptides on the oxidative stability of flaxseed oil. J. Agric. Food Chem., 62, 88-96.

Stoilova, I., Krastanov, A., Stoyanova, A., Denev, P., Gargova, S. (2007). Antioxidant activity of a ginger extract (Zingiber officinale). Food Chemistry, 102, 764-770.

Tai, A, Sawano, T, Yazana, F., Ito, H. (2011). Evaluation of antioxidant activity of vanillin by using multiple antioxidant assays. Biochim. Biophys. Acta, 1810 (2), 170-175.

Tan, J. B. L., Lim, Y. Y. (2015). Critical analysis of current methods for assessing the in vitro antioxidant and antibacterial activity of plant extracts. Food Chem., 172, 814-822.

Tirzitis, G., Bartosz, G. (2010). Determination of antiradical and antioxidant activity: Basic principles and new insights. Acta Biochim. Pol., 57 (1), 139-142.

White, P. J. (1995). Conjugated diene, anisidine value, and carbonyl value analyses. In: Warner, K., Eskin, N. A. M. (Eds.) Methods to Assess Quality and Stability of Oils and Fat-Containing Foods. AOCS Press, Champaign, Illinois, pp. 159-178. 


\section{KONJUGĒTO DIĒNU VEIDOŠANĀS INHIBĒŠANA LINSĒKLU EḶL,Ā}

Tauku un ellıu oksidēšanās samazina pārtikas uzturvērtību un rada dažādas veselības problēmas. Antioksidantu pievienošana novērš tauku oksidēšanos pārtikas produktos. Antioksidantu aktivitāte raksturo spēju inhibēt oksidēšanās procesu. Parasti augu ekstraktu antioksidantu aktivitāti nosaka linolskābes emulsijā. Pētījuma mērķis bija novērtēt konjugēto diēnu veidošanās inhibēšanu Latvijas linsēklu eḷıā. Tika salīdzināta antioksidantu aktivitāte etanola ekstraktam no Hibiscus sabdariffa L. kauslapām, vanilīnam, $\alpha$-tokoferolam, 2,6-diterc-butil-4-metilfenolam. Linsēklu eḷlas paraugi ar piedevām tika turēti 24 stundas $60{ }^{\circ} \mathrm{C}$ temperatūrā un tad analizēti, izmantojot UV spektrofotometriju $(\lambda=234 \mathrm{~nm})$. Piedevu antioksidantu aktivitāte raksturota procentuāli atkarībā no konjugēto diēnu veidošanās. Spēja inhibēt oksidēšanas procesu linsēklu eḷıā piemīt ekstraktam no Hibiscus sabdariffa L. kauslapām, tā samazinās sekojoši: vanilīnam, 2,6-diterc-butil-4-metilfenolam, $\alpha$-tokoferolam. Mūsu rezultāti rāda, ka linsēklu eḷıa var tikt izmantota vielu antioksidantu aktivitātes noteikšanai. 